\title{
Bimatoprost ophthalmic solution $0.03 \%$ lowered intraocular pressure of normal-tension glaucoma with minimal adverse events. [Corrigendum]
}

\author{
Tsumura T, Yoshikawa K, Suzumura H, Kimura T, Sasaki S, \\ Kimura I, Takeda R. Clinical Ophthalmology. 2012;6:1547-1552.
}

On page 1549 the significant difference in MD values was stated as:

$(-5.22 \pm 4.07 \mathrm{~dB}$ and $-2.72 \pm 4.06 \mathrm{~dB}, P=0.0385)$

It should have been:

$(-5.47 \pm 4.78 \mathrm{~dB}$ and $-5.26 \pm 5.22 \mathrm{~dB}, P=0.6757)$

Figure 2 legend was missing the words:

Left axis relates to the bars and right axis relates to the line chart.

\section{Publish your work in this journal}

Clinical Ophthalmology is an international, peer-reviewed journal covering all subspecialties within ophthalmology. Key topics include: Optometry; Visual science; Pharmacology and drug therapy in eye diseases; Basic Sciences; Primary and Secondary eye care; Patien Safety and Quality of Care Improvements. This journal is indexed on

Submit your manuscript here: http://www.dovepress.com/clinical-ophthalmology-journal
PubMed Central and CAS, and is the official journal of The Society of Clinical Ophthalmology (SCO). The manuscript management system is completely online and includes a very quick and fair peer-review system, which is all easy to use. Visit http://www.dovepress.com/ testimonials.php to read real quotes from published authors. 